Proc. Estonian Acad. Sci. Eng., 2003, 9, 4, 304-316

\title{
Applications of recycled hardmetal powder
}

\author{
Sergei Zimakov ${ }^{\mathrm{a}}$, Toomas Pihl ${ }^{\mathrm{b}}$, Priit Kulu ${ }^{\mathrm{a}}$, Maksim Antonov ${ }^{\mathrm{a}}$, \\ and Valdek Mikli ${ }^{\mathrm{c}}$ \\ a Department of Materials Technology, Tallinn Technical University, Ehitajate tee 5, 19086 Tallinn, \\ Estonia; pkulu@edu.ttu.ee \\ b Department of Mechatronics, Tallinn Technical University, Ehitajate tee 5, 19086 Tallinn, Estonia; \\ toomasp@staff.ttu.ee \\ c Centre for Materials Research, Tallinn Technical University, Ehitajate tee 5, 19086 Tallinn, \\ Estonia; miku@staff.ttu.ee
}

Received 7 July 2003

\begin{abstract}
This paper is devoted to the study of hardmetal powders of different particle shape, produced from used hardmetal by a mechanical disintegrator milling technology. The WC-15Co hardmetal powder of 0.2 to $0.5 \mathrm{~mm}$ with angular and round particle shape has been investigated. Particle granularity is characterized by the mean particle size and the angularity of milled powders is described by the so-called "spike parameter". The influence of the hardmetal particle angularity on the erosion rate of different metallic materials has been determined. The experiments showed that this parameter is crucial in abrasive particle shape characterization. The wear resistance of composite coatings, based on self-fluxing alloy and hardmetal powders of different particle shape, was studied. These coatings showed minimal difference in their wear resistance.
\end{abstract}

Key words: hardmetal powder, angularity, abrasivity, powder coatings, wear resistance.

\section{INTRODUCTION}

Recycled metals are becoming increasingly important as industry response to public demands that resources should be conserved and the environment protected $\left[^{1}\right]$. Hardmetal (WC-based) wastes are a part of metal scrap. With hardmetal prices rising, their recycling has become an urgent issue. One of the ways of old materials recycling is to produce powder materials from the worn products $\left[{ }^{2,3}\right]$. To produce materials, competitive in cost with primary products, secondary producers have to pursue new technologies and other innovations $\left[{ }^{1}\right]$. Recycling of metal wastes and worn materials by mechanical milling in a disintegrator mill is a prospective technology for sustainable production of metallic powders with different properties $\left[{ }^{4}\right]$. 
The main properties of powders are their granularity (particle size) and morphology. Technological properties of powders (bulk density, flowability, compatibility, etc.) as well as the potential areas of their application depend on their granularity and morphology. For thermal spray, their preferable particle form is spherical to ensure high flowability of powders and optimal conditions of particle spraying and melting. These are preconditions for producing high-density and high wear-resistant sprayed or melted coatings.

Used as abrasive material in abrasive tools, hard-powder particles must have high abrasivity. It means that they should be sharp-edged (angular in form). The same problem occurs with abrasive wear. The wear caused by abrasive grits depends on their size, shape, hardness, etc.

\section{EXPERIMENTAL}

\subsection{Description of the hardmetal powder used}

We produced hardmetal powder using the following technologies $\left[{ }^{5,6}\right]$ :

- preliminary thermo-cyclical treatment and mechanical size reduction of worn hardmetal parts by collision in a centrifugal-type mill;

- final milling of pretreated particles by collision in a disintegrator mill.

Depending on the milling cycles in a laboratory disintegrator mill DSL-160, the size and shape characteristics of the $1 \mathrm{X}, 2 \mathrm{X}, 4 \mathrm{X}, 8 \mathrm{X}, 16 \mathrm{X}$, and $32 \mathrm{X}$ milled powder particles were analysed $\left[{ }^{6}\right]$. We used hardmetal powder with different shape as abrasive in wear tests and as a reinforcement in wear resistant composite coatings. In our experiments the particle size of the hardmetal powder was from 0.2 to $0.5 \mathrm{~mm}$ (Figs. 1 and 2).

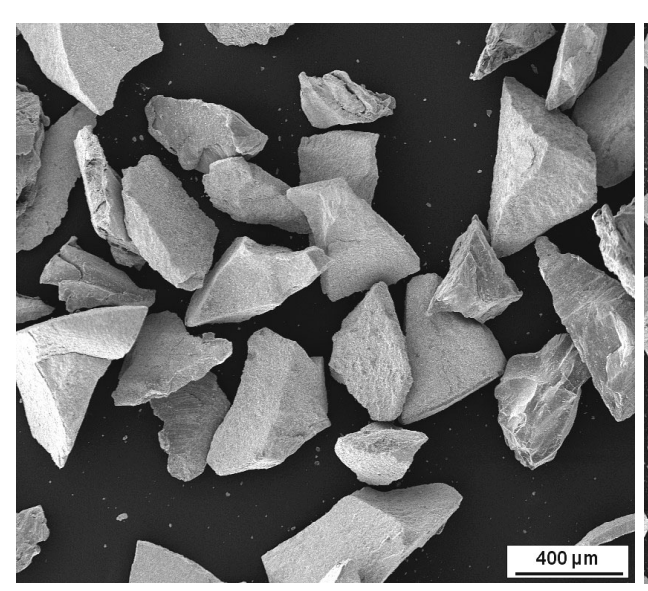

(a)



(b)

Fig. 1. SEM picture of investigated WC-Co powders: $a-1 X$ milled; $b-1 X+8 X$ milled. 


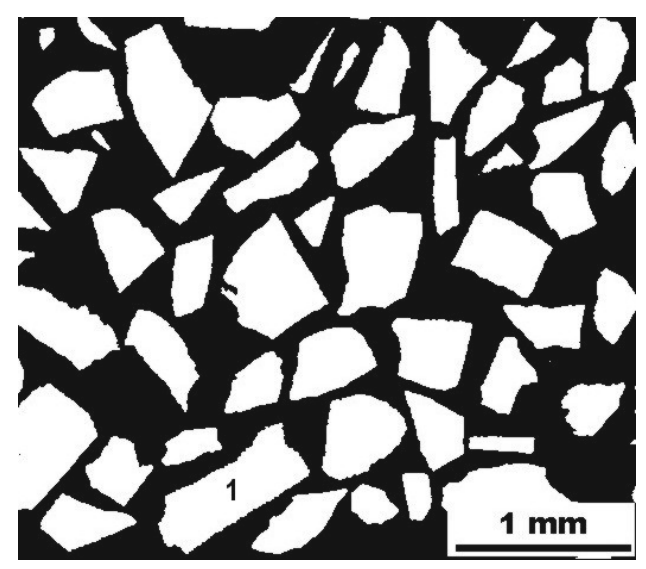

(a)

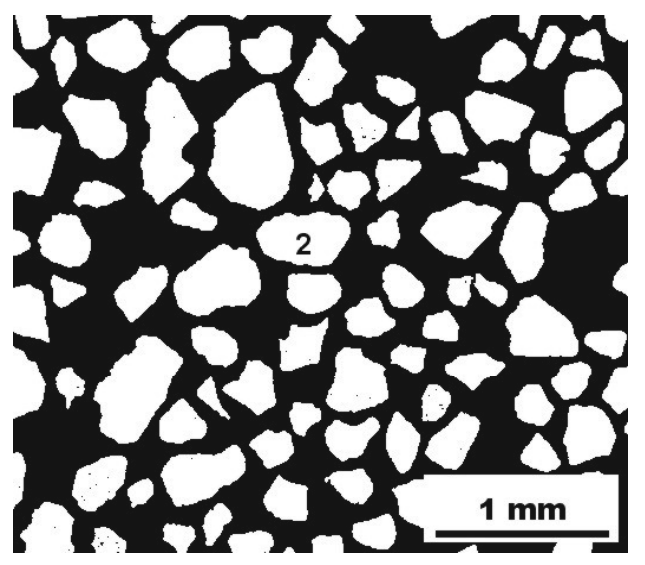

(b)

Fig. 2. Binary images at cross-sections of investigated WC-Co powders: $a-1 X$ milled; $b-1 X+8 X$ milled.

We determined the influence of powder particle shape (spheroidal, angular) on the erosion rate and the wear mechanism of different metallic materials and also the influence of the shape of the reinforcement (powder particles in composite spray fusion coatings) on the erosion wear resistance of coatings.

To characterize the granularity of particles, we measured the mean particle size and calculated the volume distribution function, the median of the particle size, and the probability density function of the particle volume $\left[{ }^{6}\right]$. To describe the angularity of milled powders, the methodology proposed by Stachowiak $\left[{ }^{7,8}\right]$ and the spike parameter (quadratic fit, $S P Q$ ) was used and real experiments were performed to determine $S P Q$ sensitivity and precision to characterize particle angularity (Fig. 3). Table 1 shows the shape and angularity parameters of the hardmetal powders used.

Table 1. Main characteristics of the powder particles

\begin{tabular}{l|c|c}
\hline \multicolumn{1}{c|}{ Size and shape factors } & \multicolumn{2}{c}{ Number of milling cycles } \\
\cline { 2 - 3 } & $1 \mathrm{X}$ & $1 \mathrm{X}+8 \mathrm{X}$ \\
\hline Mean diameter $d_{m}, \mu \mathrm{m}$ & 316 & 235 \\
Aspect ratio $A S$ & 2.00 & 1.51 \\
Roundness $R N$ & 1.52 & 1.21 \\
Irregularity parameter $I P$ & 2.43 & 1.75 \\
Angularity parameter $S P Q$ & 0.69 & 0.49
\end{tabular}




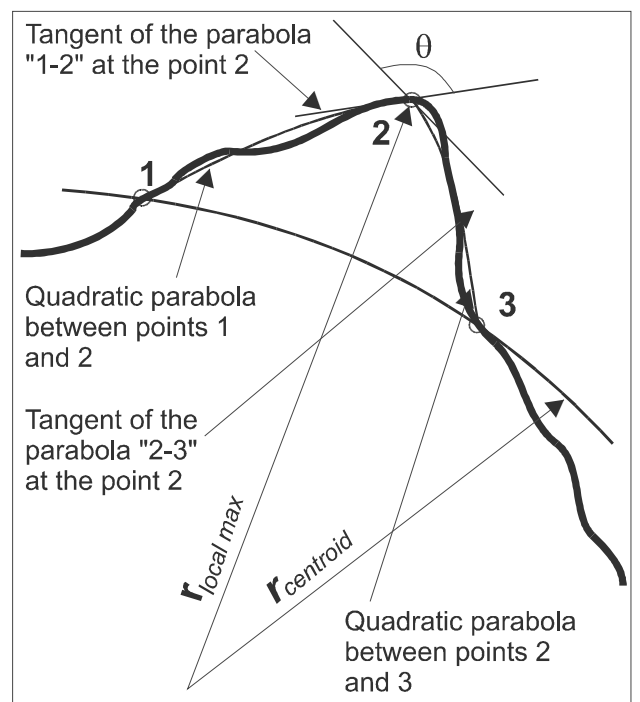

(a)

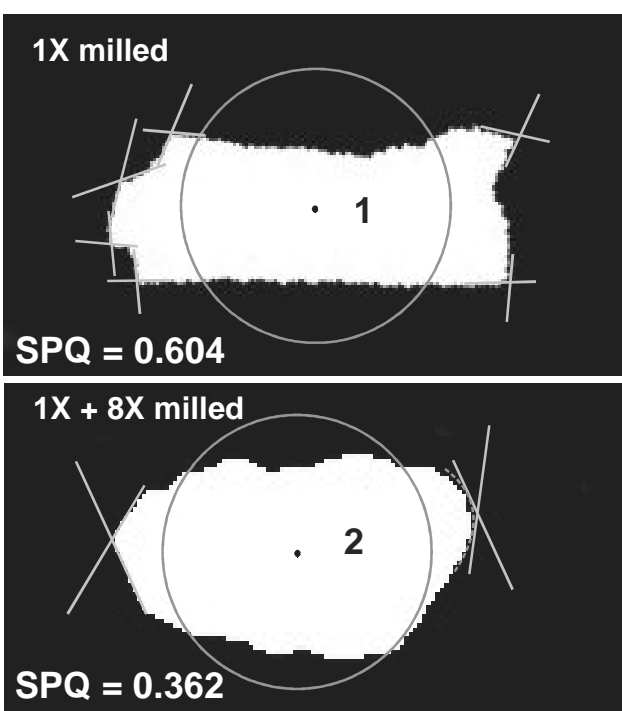

(b)

Fig. 3. Determination of the apex angle $\Theta$ : $a$-basic principles; $b$ - for real particles 1 and 2 from Figs. 2a and $2 \mathrm{~b}$, respectively.

\subsection{Hardmetal-based coatings}

To produce composite powder coatings based on the self-fluxing alloy and recycled hardmetal powder, the following thermal spray technologies were used:

- flame spray and fusion (FSF) of powder composite 25\% (WC-Co)+75\% $\mathrm{NiCrSiB}$ self-fluxing powder (Castolin SA),

- high-velocity oxy-fuel (HVOF) spray of composite powder $85 \%$ (WC-Co) $+15 \%$ Co.

A composite powder based on the recycled hardmetal powder for HVOF spray was produced by the agglomerating/sintering/crushing technology [ $\left.{ }^{9}\right]$. Thickness of coatings varied from $0.2-0.3 \mathrm{~mm}$ (HVOF sprayed coating) up to $1 \mathrm{~mm}$ (FSF coating).

\subsection{Modelling of wear}

Modelling of impact erosion (a study of wear rate and wear mechanism) was performed in an impact erosion wear tester to test materials in an abradant particle jet (Fig. 4). WC-Co powders were used as an abrading material to study the erosion wear at different impact angles. As target materials, normalized steel $\mathrm{C} 45(0.45 \% \mathrm{C})$ and pure aluminium $\mathrm{Al} 99.5(99.5 \% \mathrm{Al})$ was used. Erosion rate $v_{v}$ was calculated by the formula:

$$
v_{v}=\frac{\text { Material loss }}{\text { Weight of abrasive } \cdot \text { Density }}, \frac{\mathrm{mm}^{3}}{\mathrm{~kg}},
$$



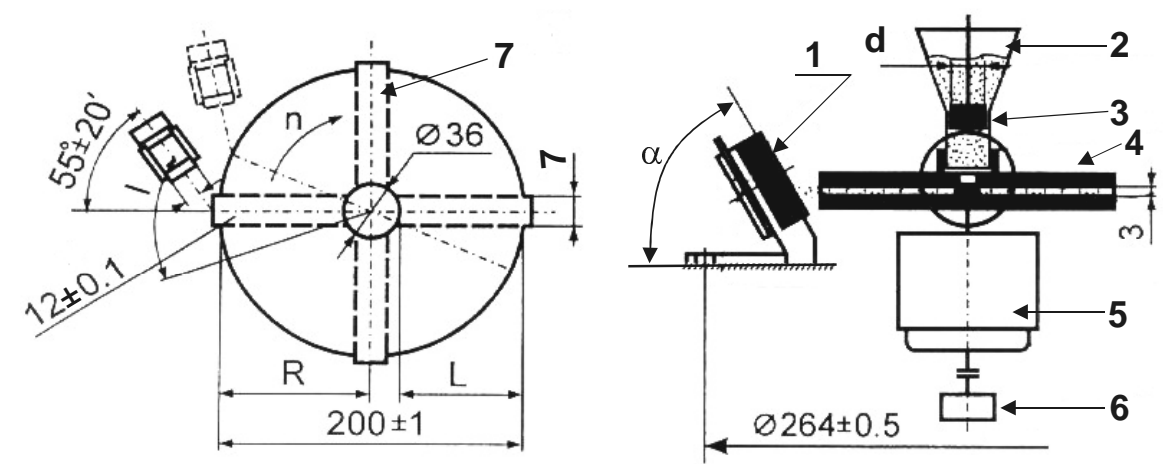

Fig. 4. Principal scheme of an erosion wear tester: 1 - specimen, 2 - abrasive particles vessel, 3 - shield, 4 - rotor, 5 - drive motor, 6 - rotation frequency gauge, 7 - radial rotor channels.

where density of steel $\mathrm{C} 45$ is $7.85 \mathrm{~g} / \mathrm{cm}^{3}$ and of $\mathrm{Al} 99.5$ is $2.7 \mathrm{~g} / \mathrm{cm}^{3}$; the dimension of the material loss is $\mathrm{g}$ and that of the weight of the abrasive $\mathrm{kG}$.

Composite coatings, reinforced with hardmetal particles of different shape (spheroidal, angular), were tested in the same impact erosion tester.

Based on the weight loss, the volume erosion rate $v_{v}$ and the relative volume wear resistance $E_{v}$ were calculated as the ratio of the volume erosion rates of the studied and reference material $(0.45 \%$ steel with hardness $200 \mathrm{HV})$ :

$$
E_{v}=\frac{v_{v}^{\text {coating }}}{v_{v}^{\text {steel }}} .
$$

Semi-industrial tests of thermally sprayed coatings were carried out in the disintegrator type mill DESI (Fig. 5), which had working pins with protective

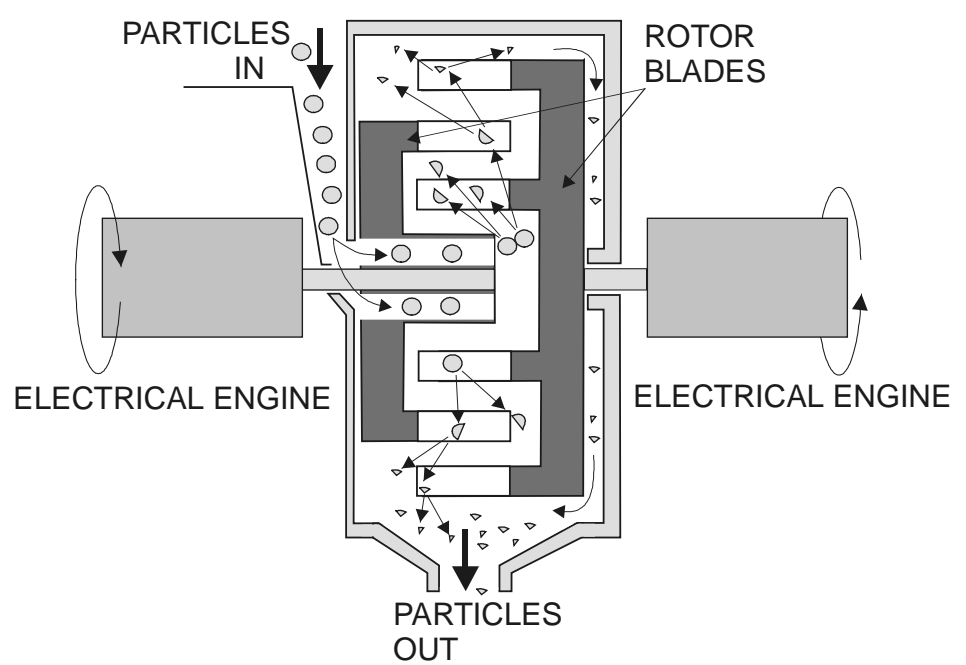

Fig. 5. Principal schematic of a disintegrator mill. 
coatings, based on self-fluxing alloy and WC-Co hardmetal powders. We used two types of materials to be treated: glass of $550 \mathrm{HV}$ and quartz sand of 1100 $1200 \mathrm{HV}$ with abrasivity $A=0.83$ and 1.0 , respectively. The coefficient of abrasivity $A$ was determined by as

$$
A=\frac{v_{\mathrm{m}}^{\text {treated }}}{v_{\mathrm{m}}^{\text {quartz sand }}},
$$

where $v_{\mathrm{m}}$ is the wear rate by weight, $\mathrm{mg} / \mathrm{kg}$.

\section{RESULTS AND DISCUSSIONS}

\subsection{Influence of the abrasive/hardmetal particle angularity on erosion}

A direct correlation between the shape of abrasive particles and the wear rate at the oblique impact was found (Fig. 6). Figure 6a shows the influence of angularity (angular $1 \mathrm{X}$ and round $1 \mathrm{X}+8 \mathrm{X}$ milled) of an abrasive on the wear rate of steel $(0.45 \% \mathrm{C})$ at different impact angles $\alpha$. At a low operating angle $\left(30^{\circ}\right)$, the erosion rate is doubled in the case of angular particles. At $90^{\circ}$ the wear rate did not depend significantly on the particle angularity and was slightly higher in round particles. Figure $6 \mathrm{~b}$ shows the results of the same study, using pure aluminium as a target material. The difference in the wear rate of angular and round abrasive particles is practically the same as by steel. Due to low hardness and high plasticity at the small $\left(30^{\circ}\right)$ impact angle, the wear rate exceeded that of steel more than for six times.

Figure 7 shows the wear marks of eroded surfaces of the steel C45 by angular and round particles of the abrasive. As it follows from Figs. $7 \mathrm{a}$ and $\mathrm{c}$, at a low

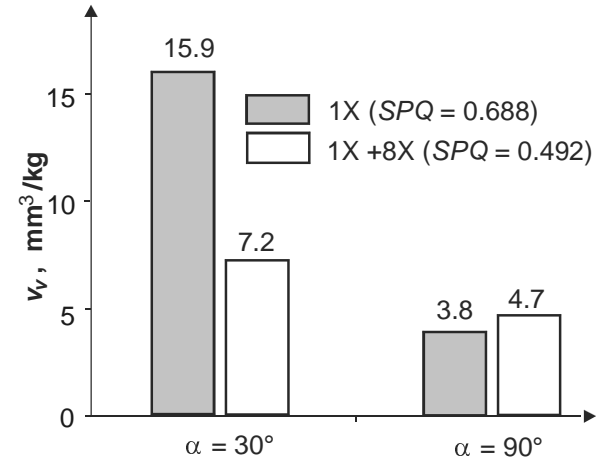

(a)

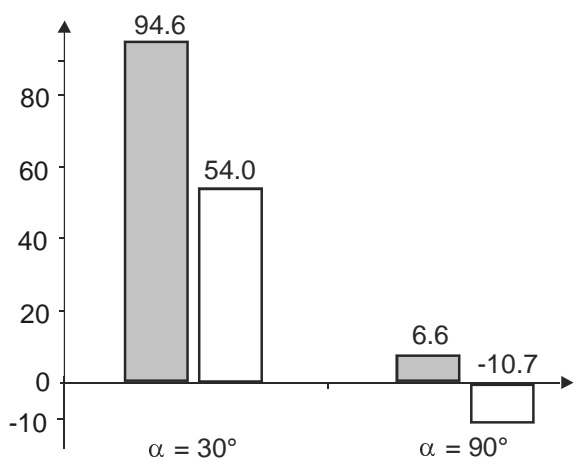

(b)

Fig. 6. Influence of the abrasive particle angularity on the erosion rate of metallic materials at different impact angles: a - steel C45; b - A199.5. 


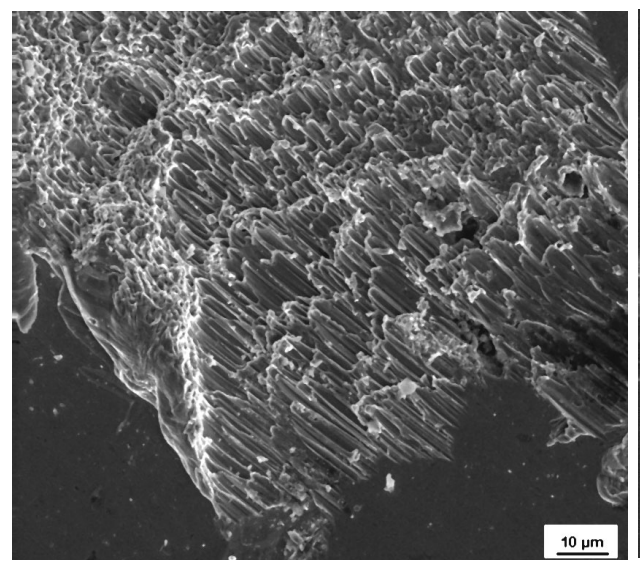

(a)

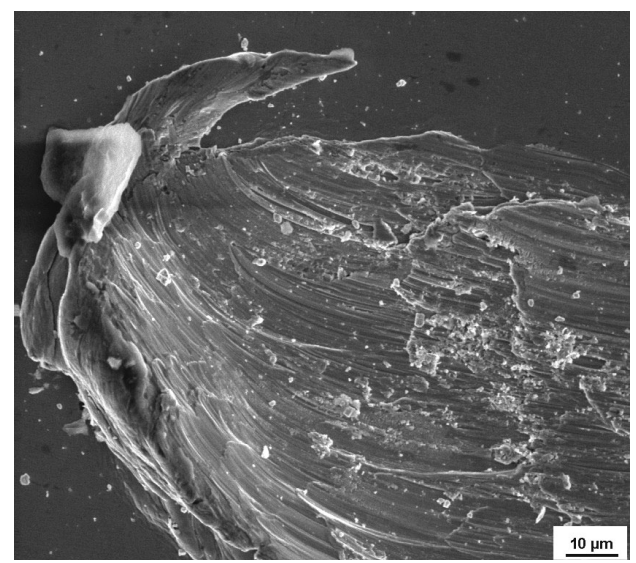

(c)

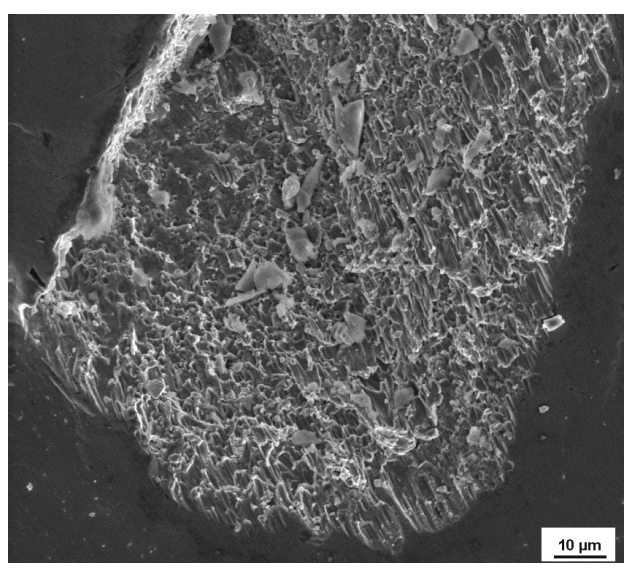

(b)

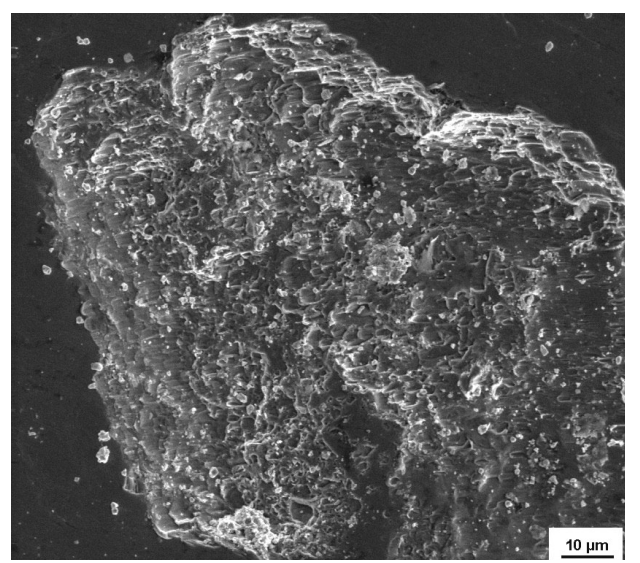

(d)

Fig. 7. SEM pictures of wear marks of eroded surfaces by angular $(a, b)$ and round $(c, d)$ abrasive particles of steel C45 at low (a, c) and high (b, d) impact angle.

impact angle, both by angular and round abrasives a plastic deformation takes place with the micromachining mechanism dominating. When high impact angles were applied (Figs. $7 \mathrm{~b}$ and d), the surface was subjected only to plastic deformation and the wear rate was minimal.

At normal impact $\left(90^{\circ}\right)$, the penetration of hardmetal particles to the $\mathrm{Al}$ target took place. As a result, by angular abrasive particles the weight of the specimen increased (the wear rate by the round abrasive is negative, Fig. 6b). 


\subsection{Structure and properties of thermally sprayed recycled hardmetal- based coatings}

The hardmetal powder, manufactured through single and multiple milling processes, which resulted in powder particles with different shape (angular and round) was used for thermal spray. On the basis of $\mathrm{NiCrSiB}$ self-fluxing alloy powder, containing about $25 \mathrm{wt} \%$ of WC-Co hardmetal particles (particle sizes between 0.2 and $0.5 \mathrm{~mm}$ ) of angular and round shape, composite coatings were manufactured by different spray and fusion methods (flame spray fusion (FSF), flame spray with the following induction fusion (FSIF), and high velocity oxyfuel spray (HVOFS)). The composition and properties of composite coatings are shown in Table 2.

Table 2. Properties of thermally sprayed composite coatings

\begin{tabular}{c|c|c|c|c}
\hline Coating type & \multirow{2}{*}{$\begin{array}{c}\text { Shape of hard phase } \\
\text { particles }\end{array}$} & \multirow{2}{*}{$\begin{array}{c}\text { Deposition } \\
\text { technique }\end{array}$} & \multicolumn{2}{|c}{ Hardness HV0.2 } \\
\cline { 4 - 5 } & & Metal matrix & Hard phase \\
\hline NiCrSiB+25wt\%VK15 & angular & FSF & 755 & 1400 \\
& round & & 660 & \\
NiCrSiB+25wt\%VK15 & angular & FSIF & 685 & 1400 \\
& round & & 560 & \\
85wt\%VK15+15wt\%Co & epiaxial agglomerate & HVOFS & 1350 & 1350
\end{tabular}

Micrographical investigations of spray-fused coatings with different hard phase showed that the formation of microstructure depends on the particle shape as well as on the fusion method. By angular reinforcement, hardmetal particles are partially dissolved in the metal matrix (Fig. 8a), whereas spherical hardmetal particles have higher thermal stability than the angular ones (Fig. 8b); with angular hardmetal particles only coarser and external particles remaining insoluble. It was confirmed also by our hardness measurements (Table 2): hardness of the coating matrix at angular reinforcements exceeded that of spheroidal ones by $15-20 \%$.

A minimal difference in the wear resistance of particles of different angularity was found as a result of the wear tests (Fig. 9). 


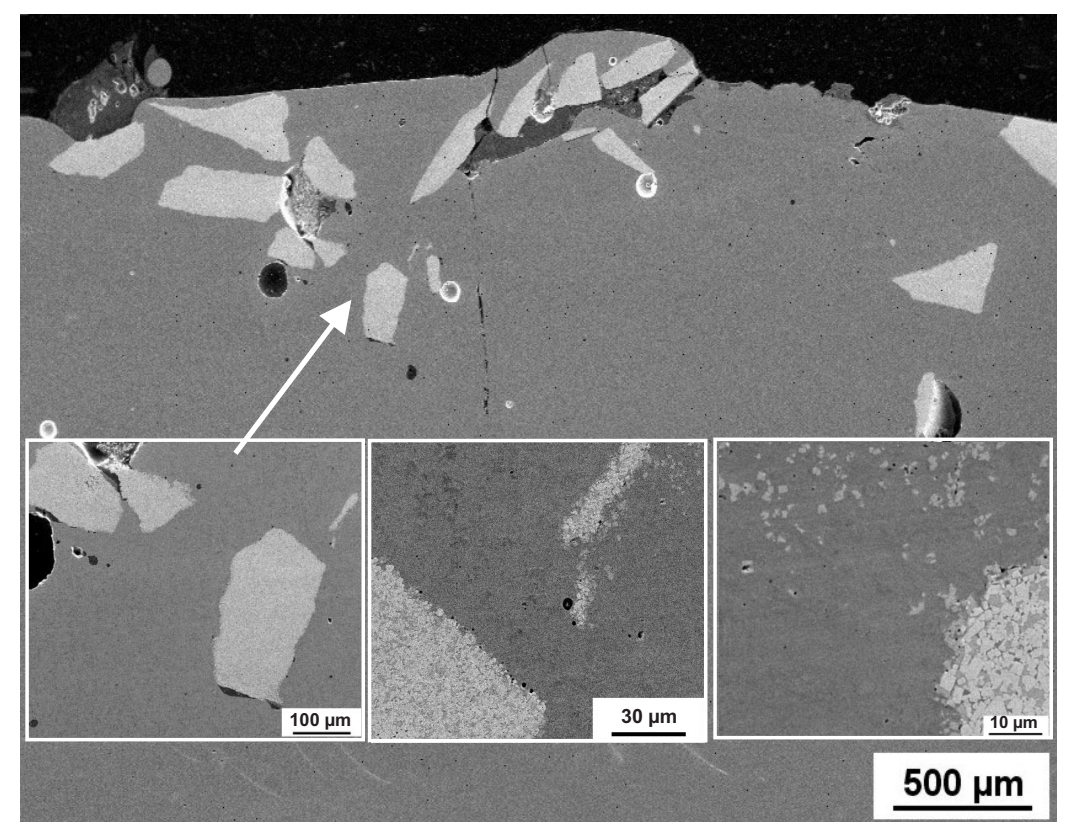

(a)

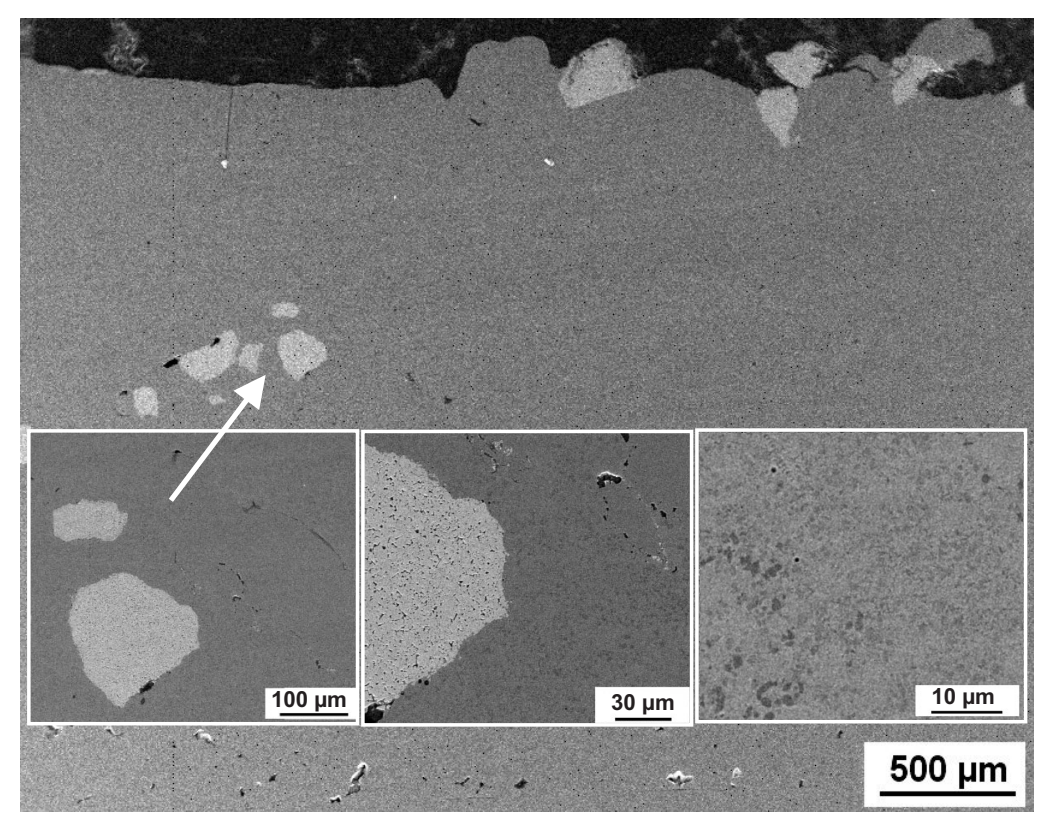

(b)

Fig. 8. Micrographs of the cross-section of FSF NiCrSiB $+25 w t \%$ (WC-Co) coatings, reinforced with hardmetal particles: $a$ - of angular shape, $b$ - of round shape. 


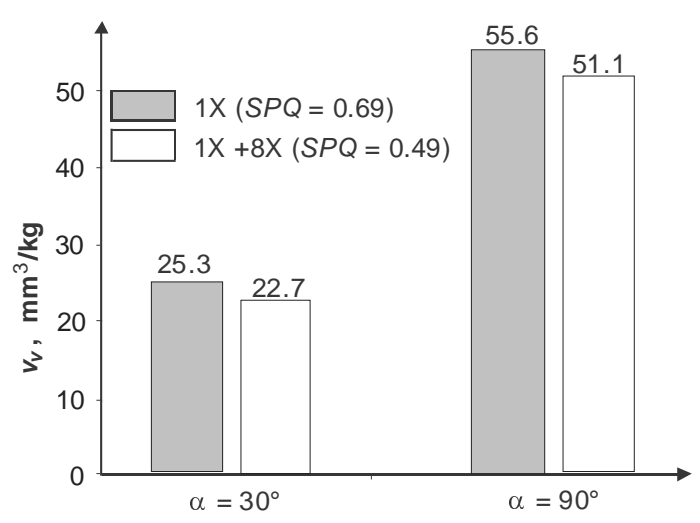

Fig. 9. Influence of WC-Co hardmetal reinforcements shape on the erosion rate of composite spray fused coatings.

\subsection{Comparative testing of thermally sprayed coatings in a disintegrator mill}

Both by using the disintegrator for crushing different materials and by milling of hard materials, intensive wear takes place. Therefore, hardfacing of disintegrator parts is important to reduce the wear and to obtain a noncontaminated milled product. The rotors of disintegrators (pins and disks) are subjected to hard wear. To decrease the wear, different coatings for hardfacing of pins were used. Hardmetal coatings and self-fluxing alloy-based coatings with hardmetal reinforcement were tested. Table 3 shows the results of testing the coatings in a disintegrator milling system DESI by treatment with different abrasive materials. In Fig. 10 SEM pictures of worn surfaces are shown.

Our previous results $\left[^{10,11}\right]$ and testing in a disintegrator showed a strong influence of erodent particle hardness on the erosive wear rate. To guarantee high wear resistance of coatings at an oblique impact, their hardness must exceed the hardness of the material to be treated. It follows clearly from the results (Table 3) that the wear resistance of coatings eroded by silica is lower than that of the

Table 3. Results of comparative testing of pins in a disintegrator

\begin{tabular}{l|c|c|c|c}
\hline \multirow{2}{*}{$\begin{array}{c}\text { Coating material and } \\
\text { deposition method }\end{array}$} & \multicolumn{4}{c}{ Treated material } \\
\cline { 2 - 5 } & \multicolumn{2}{|c|}{$\begin{array}{c}\text { Glass }(550 \mathrm{HV}) \\
A=0.83\end{array}$} & \multicolumn{2}{c}{$\begin{array}{c}\text { Quartz sand }(1100 \mathrm{HV}) \\
A=1.0\end{array}$} \\
\cline { 2 - 5 } & $v_{\mathrm{m}}, \mathrm{mg} / \mathrm{kg}$ & $\mathrm{E}_{\mathrm{v}}$ & $v_{\mathrm{m}}, \mathrm{mg} / \mathrm{kg}$ & $\mathrm{E}_{\mathrm{v}}$ \\
\hline $\begin{array}{l}\text { Reference material: steel } \\
\text { C45 (0.45\%C), normalized 200 HV }\end{array}$ & 4.74 & 1.0 & 2.03 & 1.0 \\
WC-17Co (Tafa 1343V), HVOFS & 2.47 & 1.9 & 2.41 & 0.8 \\
NiCrSiB (Tafa 1275), HVOFS & 3.66 & 1.1 & 5.31 & 0.4 \\
NiCrSiB (Tafa 1275), HVOFSF & 4.14 & 1.1 & 3.68 & 0.6 \\
NiCrBSi (12495) + 15\%WC-Co, FSF & 3.10 & 1.5 & 4.56 & 0.4
\end{tabular}




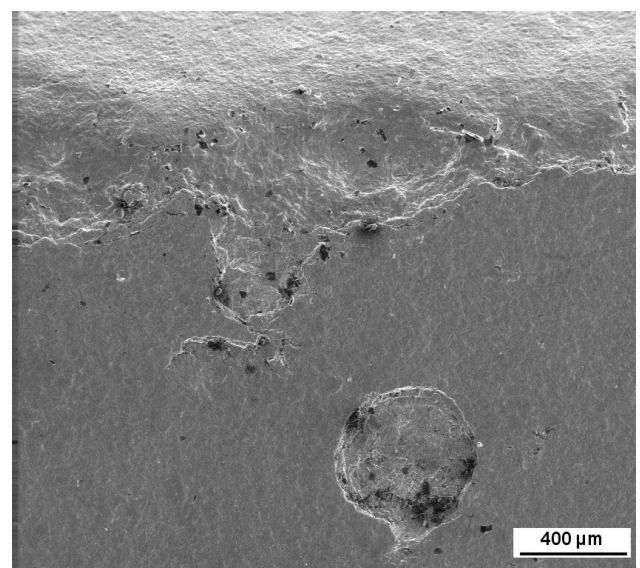

(a)

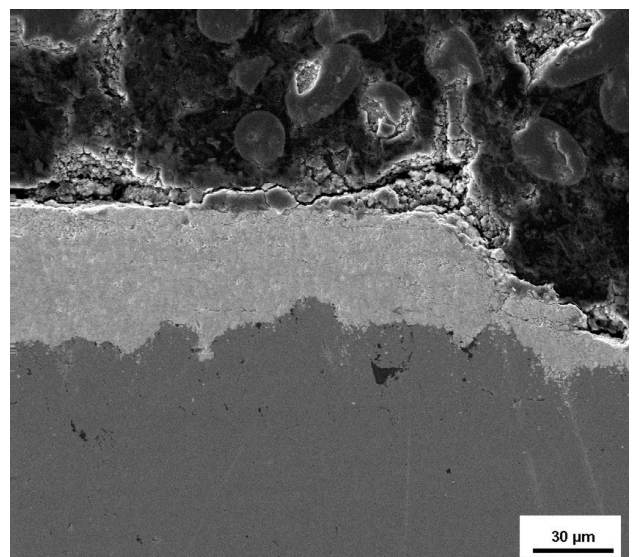

(c)

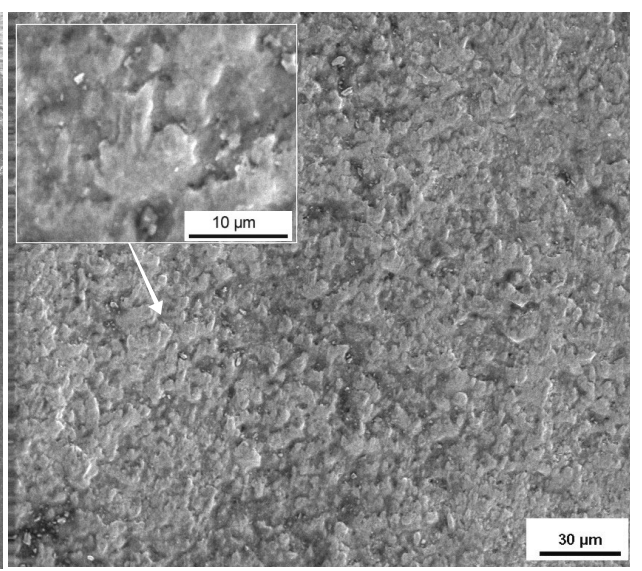

(b)

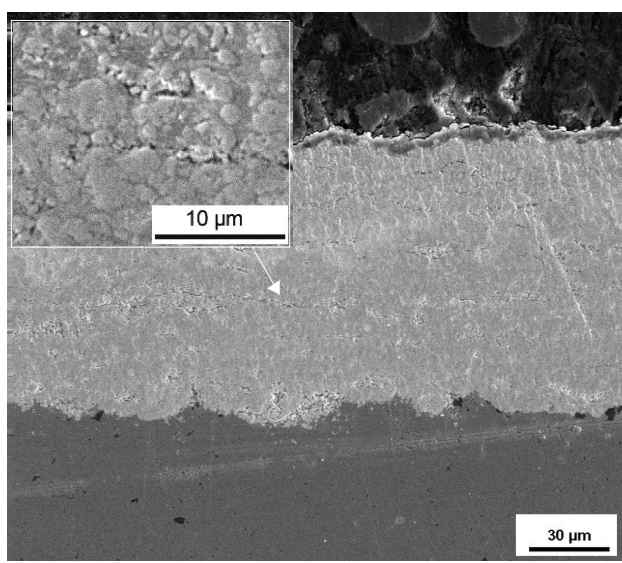

(d)

Fig. 10. SEM pictures of worn surfaces of $\mathrm{NiCrSiB}+25 \mathrm{wt} \%$ (WC-Co) coated pins of the disintegrator: $\mathrm{a}, \mathrm{b}$ - topographical images, $\mathrm{c}, \mathrm{d}$ - micrographs of the cross-section.

reference material, steel $0.45 \%$ C. Erosion by glass (500-600 HV) shows an increase in the wear resistance of coatings up to three times as compared to the reference material. It is lower than that in laboratory tests at low impact angles. However, mixed erosion occurs in a disintegrator instead of pure oblique or normal impact. In this case, the so-called "double cemented" structures, WC-Co based hardmetal particles in a metal matrix, are recommended $\left[{ }^{11}\right]$. This was confirmed by the studies of worn coated pins (Fig. 9). 


\section{CONCLUSIONS}

1. Different application areas (as an abradant and coating reinforcement) of the hardmetal powder, produced by mechanical milling from used hardmetal, were studied.

2. The influence of the hardmetal particles as an abradant with different shapes on the erosion rate was significant.

3. The influence of the shape of hardmetal reinforcements in thermally sprayed composite coatings on their erosion rate is insignificant.

4. Use of composite coatings with the so-called double cemented structure in mixed erosive wear conditions is promising.

\section{ACKNOWLEDGEMENT}

The authors are grateful to the Estonian Science Foundation for support, grants Nos. 4849, 5612, and 4864.

\section{REFERENCES}

1. Tilton, J. E. The future of recycling. Resources Policy, 1999, 25, 197-204.

2. Aboussouan, L., Russo, P., Pons, M. N., Thomas, D., Birat, J. P., and Leclers, D. Steel scrap fragmentation by shredders. Powder Technol., 1999, 105, 288-294.

3. Kawatra, S. K. and Ripke, S. J. Palletizing steel mill desulfuration slag. J. Mineral Process., 2002, 65, 165-175.

4. Tümanok, A., Kulu, P., Goljandin, D., and Roštšin, P. Disintegrator as a machine for utilizing of metal chips to metal powder. In Proc. III ASM International Conference and Exhibition. The Recycling of Metals. Barcelona, 1997, 513-522.

5. Tümanok, A., Kulu, P., Mikli, V., and Käerdi, H. Technology and equipment for production of hardmetal powders from used hardmetal. In Proc. 2nd International DAAAM Conference. Tallinn, 2000, 197-200.

6. Kulu, P., Käerdi, H., and Mikli, V. Retreatment of used hardmetals. In Proc. TMS2002 Recycling and Waste Treatment in Mineral and Metal Processing: Technical and Economic Aspects. Lulea, 2002, vol. 1, 139-146.

7. Stachowiak, G. W. Numerical characterization of wear particle morphology and angularity of particles and surfaces. Tribol. Internat., 1998, 31, 139-157.

8. Stachowiak, G. W. Particle angularity and its relationship to abrasive and erosive wear. Wear, 2000, 241, 214-219.

9. Kulu, P., Zimakov, S., Goljandin, D., and Peetsalu, P. Novel thermal spray powders for corrosion and wear resistant coatings. J. Mater. Sci. Kaunas University of Technol., 2002, 8/4, 413-416.

10. Kulu, P. and Zimakov, S. Wear resistance of thermal sprayed coatings on the base of recycled hardmetal. Surface Coatings Technol., 2000, 130, 46-51.

11. Kulu, P. Selection of powder coatings for extreme erosion wear conditions. Advanced Eng. Mater., 2002, 4/6, 392-397. 


\title{
Teisese kõvasulampulbri rakendusi
}

\author{
Sergei Zimakov, Toomas Pihl, Priit Kulu, Maksim Antonov \\ ja Valdek Mikli
}

On vaadeldud kõvasulamist desintegraatorjahvatamise teel saadud erineva osakeste kujuga kõvasulampulbri omadusi ja rakendusi. Uuriti erineva osakeste kujuga (ümarad, nurgelised) volframkarbiidsest kõvasulamist $0,2-0,5 \mathrm{~mm}$ läbimõõduga pulbri koostist ning osakeste kuju nurgelisuse kirjeldamise meetodeid. Selgitati kõvasulampulbri osakeste kuju mõju nii abrasiivina erinevate materjalide abrasiiverosioonil kui ka armatuurina iseräbustuva sulami baasil valmistatud metallmaatrikskomposiitpinnete kulumiskindlusele. 